\title{
Comparison of methods of sampling for Toxocara species and fecal coliforms in an outdoor day care environment
}

Hélène Carabin DVM MSc, Theresa W Gyorkos PhD, Evelyne Kokoskin ART MSc, Pierre Payment PhD, Lawrence Joseph PhD, Julio Soto MD PhD

H Carabin, TW Gyorkos, E Kokoskin, P Payment, L Joseph, J Soto. Comparison of methods of sampling for Toxocara species and fecal coliforms in an outdoor day care environment. Can J Infect Dis 1998;9(3):149-156.

OBJECTIVE: To compare three sampling methods and to pretest methods for the determination of fecal coliform (FC) counts and Toxocara species from sand in the day care outdoor environment.

DESIGN: The sand samples were obtained from the play area and the sandbox of a day care centre and examined for the presence of FC and Toxocara species, the common roundworm of dogs and cats. The sampling methods included random selection and two types of judgement methods. The latter included one method where domestic animals were judged to be likely to defecate and the other where children would be likely to be playing. In addition, to obtain a global estimate of contamination, the entire areas of both the sandbox and the play area were sampled on the last day.

SETTING: Outdoor day care environment.

MAIN RESULTS: The most representative levels of bacterial contamination and Toxocara species originated from the combined sample of the entire surface areas rather than from any separate random or judgement method of sampling. FCs were found in all sampled areas of the sandbox (median $910 \mathrm{FCs} / \mathrm{g}$ of sand) and of the play area (median $350 \mathrm{FCs} / \mathrm{g}$ of sand). Toxocara species were recovered from a number of areas in both the sandbox and the play area.

CONCLUSIONS: Research on environmental microbial contamination of outdoor day care settings would benefit from the application of standardized and validated sampling and laboratory methods.

Key Words: Contamination, Day care centre, Environment, Fecal coliforms, Methodology, Toxocara species

\section{Comparaison des méthodes d'échantillonnage des espèces de Toxocara et des coliformes fécaux prélevés sur un terrain de jeu d'une garderie}

OBJECTIF : Comparer trois méthodes d'échantillonnage et prétester des méthodes pour déterminer le nombre de coliformes fécaux et rechercher les espèces de Toxocara dans le sable d'une cour de garderie.

MODÈLE : Les échantillons de sable ont été prélevés dans le bac à sable et sur le terrain de jeu d'une garderie et analysés pour une recherche de coliformes fécaux (CF) et des espèces de Toxocara, le nématode commun des chiens et des chats. Les méthodes d'échantillonnage comprenaient une sélection au hasard et deux types d'échantillonnage au jugé, dont une estimant l'endroit où les animaux domestiques iraient probablement déféquer, et l'autre estimant l'endroit où les enfants iraient probablement jouer. De plus, pour obtenir une estimation globale de la contamination, des échantillons ont été prélevés dans tout le bac à sable et dans toutes les aires de jeu le dernier jour.

CONTEXTE : Terrain de jeu d'une garderie.

PRINCIPAUX RÉSULTATS : Les niveaux les plus représentatifs de contamination bactérienne et de contamination par les espèces de Toxocara provenaient de l'échantillon combiné prélevé sur les surfaces entières plutôt que d'une

voir page suivante

Department of Epidemiology and Biostatistics, McGill University, Montreal, Quebec

Correspondence and reprints: Dr Hélène Carabin, Division of Clinical Epidemiology, Montreal General Hospital, Room L10 321.1, 1650 Cedar Avenue, Montreal, Quebec H3G 1A4. Telephone 514-937-6011 ext 4729, fax 514-934-8293, e-mail hcarab@po-box.mcgill.ca

Received for publication March 19, 1997. Accepted June 11, 1997 
quelconque méthode d'échantillonnage distincte par sélection au hasard ou au jugé. On a décelé des CF dans toute les aires échantillonnées du bac à sable (médiane de $910 \mathrm{CF} / \mathrm{g}$ de sable) et des aires de jeux (médiane de $350 \mathrm{CF} / \mathrm{g}$ de sable). On a prélevé les espèces de Toxocara dans plusieurs endroits du bac à sable et du terrain de jeu.

CONCLUSIONS : La recherche sur la contamination microbienne environnementale touchant les terrains de jeu et les installations extérieures des garderies bénéficierait de l'application de méthodes d'échantillonnage et de laboratoire validées et normalisées.

$I^{t}$ is recognized that children who attend day care centres (DCCS) have a higher incidence of infectious diseases than children who do not attend DCCs (1-4). In particular, toddlers are considered to be the group at most elevated risk because their hygiene skills are not yet fully developed, they are in the 'oral' stage of their development and they are increasingly mobile (4-6). Black et al (7) have shown that children under three years of age put their hands or other objects into their mouths every 2 to 3 mins. This normal behaviour sometimes results in exposure to environmental contamination. It has been shown that fecal coliform (FC) contamination present in the indoor day care environment accounts for almost one-third of diarrhea in toddlers (5). These observations highlight the need to understand where and when microbial contamination is highest in the environment surrounding young children in order to initiate appropriate measures of prevention and control. Unfortunately, much remains unknown about the sources of microbial contamination, especially in the outdoor environment.

To date, only two studies have assessed sand- or soilassociated microorganism contamination in the outdoor environment of DCCs (ie, sandboxes and play areas). These studies, carried out in Canada (8) and in France (9), used the presence of Toxocara species as an indicator of domestic animal fecal contamination because they are a zoonosis and, therefore, of public health concern, and because they specifically represent contamination from domestic animal sources (dogs and cats). Both studies showed that this parasite is present in outdoor DCC play areas. Seasonality of contamination may occur, but in sandboxes of three nursery schools in Marseille (France), Toxocara species ova were recovered throughout the year (9). Animal feces can also contain viral (eg, rotavirus) and bacterial microorganisms (eg, Escherichia coli) (10). These microorganisms can remain viable in the environment for some time, especially in fecal matter (11). FC contamination has been reported in sandboxes in parks of the Angers region of France (12) and in lawns and sandboxes of parks in Poland (13). Birds may also be a potential source of contamination because they shed microorganisms in their droppings that can be infectious to humans (10). In Canada, one-third of seagulls in the Montreal area were shown to carry Salmonella species, Listeria monocytogenes and Campylobacter species in their cloacae (14). Transmission of these microorganisms to young children via the outdoor environment is thus possible, but the magnitude of risk remains unknown.

Guidelines regarding the prevention and control of contamination of sand and toys in outdoor DCC playgrounds have been established by public health authorities in Quebec (15), in Canada (16) and in the United States (17). However, these guidelines vary from one authority to another. Moreover, their efficacy and effectiveness have not been evaluated.
Numerous studies have assessed the presence of Toxocara species in sandpits, sandboxes and soil in public parks, kindergardens, schools, gardens and backyards. A comprehensive list of the results of these studies is shown in Table 1 . The great variation in results is immediately apparent and highlights several issues. First, identification of Toxocara species from the outdoor environment is recognized internationally as an important indicator of potential pathogenic contamination. Second, there is a lack of documentation from day care centres, settings that may previously have been thought to present little risk of exposure. Third, sampling methodology differs greatly from one study to the next. Lastly, there is a large amount of information missing from the published reports.

The details of the various sampling and laboratory methodologies used in previous studies are shown in Table 2 . The types of sampling most frequently used were random, systematic and two types of judgement: one, where children would play, and two, where domestic animals would be expected to defecate (eg, shaded areas, near walls). When reported, the depth and surface from which the sand or soil specimens were sampled and the weight of sample varied extensively. A similar observation was found with respect to laboratory methods used. Missing information combined with the great variation in methods provide insufficient evidence for an accurate assessment of the occurrence and/or intensity of microbial contamination reported in this literature.

Based on the above considerations, we designed a study with two objectives: to compare three of the most commonly used types of sampling methods (one random and two types of judgement sampling), and to pretest field and laboratory methods for the determination of Toxocara species and FC counts from sand.

\section{METHODS}

Selection of the study DCC: The sampling frame consisted of 10 DCCs located in the Montreal and Laval regions of Quebec. Participating DCCs had at least one outdoor sandbox and play area. One $100 \mathrm{~g}$ sample of sand from each DCC was examined for the presence of FCs. Of the 10 DCCs, six were found to have no FCs (or a coliform level below that detectable at the screening dilution). Contamination levels found at the other four centres were $1 \mathrm{FCs} / \mathrm{g}, 40 \mathrm{FCs} / \mathrm{g}, 660 \mathrm{FCs} / \mathrm{g}$ and $1600 \mathrm{FCs} / \mathrm{g}$, respectively. The DCC having the highest number of FCs was selected for this study.

Sampling methods: Surfaces of both the sandbox and the play area were measured and divided into 25 areas of approximately equal size (Figure 1). The grid coordinates for the areas were indicated on the sides of the sandbox and the play area with a black marker. A total of 25 areas were, therefore, identified and numbered from 1 to 25 . 
TABLE 1

Reported prevalence of Toxocara species in outdoor environments by country

\begin{tabular}{|c|c|c|c|c|c|c|}
\hline \multirow[b]{2}{*}{ Reference } & \multirow[b]{2}{*}{ Year } & \multirow[b]{2}{*}{ Country } & \multirow[b]{2}{*}{ Number of sites and type } & \multirow{2}{*}{$\begin{array}{c}\text { Number of samples } \\
\text { per site (total) }\end{array}$} & \multicolumn{2}{|c|}{ Prevalence number (\%) } \\
\hline & & & & & Per site & Per sample \\
\hline 18 & 1984 & Australia & 6 parks & $?(?)$ & 0 & 0 \\
\hline 19 & 1990 & Australia & 41 sandpits in 30 kindergardens & $2-3(?)$ & 0 & 0 \\
\hline 20 & 1994 & Brazil & 39 parks & 5 (195) & $9(23)$ & $?$ \\
\hline \multirow[t]{2}{*}{21} & 1976 & Canada & 10 parks & $1-5$ & $6(60)$ & $14(33)$ \\
\hline & & & 33 sandboxes in 10 parks & & & 7 (18) \\
\hline 22 & 1986 & Canada & 21 playgrounds in parks & $?(510)$ & 11 parks (5) & $8(2)$ \\
\hline 8 & 1994 & Canada & 10 play areas in 10 DCCs & $10(100)$ & $2(20)$ & $?$ \\
\hline 23 & 1980 & France & 17 parks & $?$ & $11(65)$ & $?$ \\
\hline 24 & 1982 & France & 15 sandboxes in 8 parks & $4-11(58)$ & 2 (13) in 1 park & $4(7)$ \\
\hline 9 & 1986 & France & 13 sandboxes: 10 parks, 3 DCCs & $?$ & $8(62): 2$ DCCs & $?$ \\
\hline 25 & 1994 & France & $\begin{array}{l}5 \text { sandboxes: } 3 \text { parks, } 2 \text { kinder- } \\
\text { gardens }\end{array}$ & $10(50)$ & $4(80)$ & $17(34)$ \\
\hline 26 & 1984 & Germany & 31 sandpits: ? & $4-10(562)$ & $27(87)$ & $?$ \\
\hline 27 & 1987 & Germany & 18 sandboxes & $?(86)$ & $4(22)$ & $4(5)$ \\
\hline 28 & 1990 & Germany & 52 sandpits in playground & $4(208)$ & $29(56)$ & $51(25)$ \\
\hline \multirow[t]{2}{*}{29} & 1991 & Ireland & 26 gardens & $?$ & $10(38)$ & $?$ \\
\hline & & & 17 parks & $2-6(53)$ & $2(12)$ & $3(6)$ \\
\hline 30 & 1994 & Ireland & 9 playgrounds & $12-40(228)$ & $8(89)$ & $35(15)$ \\
\hline \multirow[t]{2}{*}{31} & 1993 & Japan & 24 sandpits in parks & $5(120)$ & $21(80)$ & $?$ \\
\hline & & & 22 sandpits in kindergardens & $5(110)$ & $8(36)$ & ? \\
\hline 32 & 1993 & Japan & 13 sandpits in parks & $5-8(?)$ & $12(92)$ & ? \\
\hline \multirow[t]{2}{*}{33} & 1989 & Jordan & ? schools & ? (86) & $?$ & $5(6)$ \\
\hline & & & ? public places & $?(94)$ & $?$ & $7(8)$ \\
\hline 34 & 1986 & La Réunion* & 13 playgrounds: park and school & 1 & $6(46)$ & $6(46)$ \\
\hline \multirow[t]{2}{*}{35} & 1993 & Netherlands & 27 parks & $6(162)$ & $?$ & $13(8)$ \\
\hline & & & ? sandboxes & $2(61)$ & $?$ & $15(25)$ \\
\hline 36 & 1980 & Scotland & ? parks & $?(234)$ & $?$ & $17(7)$ \\
\hline \multirow[t]{2}{*}{37} & 1989 & Spain & 132 urban park, street & $1(132)$ & $6(5)$ & $6(5)$ \\
\hline & & & 310 rural play areas & 1 (310) & $28(9)$ & $28(9)$ \\
\hline 38 & 1973 & United Kingdom & 10 parks & 40 (400) & $10(100)$ & $93(23)$ \\
\hline \multirow[t]{2}{*}{39} & 1987 & United Kingdom & 5 play areas in 5 parks & Vary (226) & $5(100)$ & $147(65)$ \\
\hline & & & 5 parks & Vary (277) & $5(100)$ & $169(61)$ \\
\hline 40 & 1991 & United Kingdom & 8 parks & $8-229(521)$ & $7(88)$ & $33(6)$ \\
\hline 41 & 1975 & United States & 2 parks & 42 and 48 (90) & $2(100)$ & $26(29)$ \\
\hline \multirow[t]{2}{*}{42} & 1979 & United States & 23 swing areas in 10 parks & $1(23)$ & $4(17)$ & $4(17)$ \\
\hline & & & 23 sandboxes in 10 parks & $1(23)$ & $9(39)$ & $9(39)$ \\
\hline 43 & 1980 & United States & 32 play areas in parks & Vary (285) & $1(3)$ & $1(0.4)$ \\
\hline 44 & 1984 & United States & 20 parks & ? (1529) & $4(20)$ & $6(0.4)$ \\
\hline 45 & 1985 & United States & 146 backyards & $3(438)$ & $16(11)$ & $?$ \\
\hline 46 & 1988 & United States & 23 play areas in parks & Vary (135) & $11(48)$ & $22(16)$ \\
\hline 47 & 1989 & United States & 3 parks & $13-53(114)$ & $2(67)$ & $22(19)$ \\
\hline 48 & 1983 & Yugoslavia & 10 parks & $10(100)$ & $8(80)$ & $27(27)$ \\
\hline
\end{tabular}

*La Réunion is an Overseas French Department (France). ? Indicates that this information is not provided in the publication. DCC Day care centre

On each day over a nine-day period, five areas from the sandbox and five areas from the play area were sampled for a total of 90 sand samples. The areas sampled varied from day to day according to the method used, random or by judgement (two types). The methods are described below.
Random method (R): Five numbers from 1 to 25 were selected at random using a table of random numbers. The areas corresponding to the selected numbers were sampled. The numbers selected for the sandbox differed from the ones selected for the play area. 
TABLE 2

Methodologies used in the recovery of Toxocara species ova from sand and soil

\begin{tabular}{|c|c|c|c|c|c|c|c|}
\hline \multirow[b]{2}{*}{ Reference } & \multicolumn{4}{|c|}{ Sampling methods } & \multicolumn{3}{|c|}{ Laboratory method } \\
\hline & Type* & Depth $(\mathrm{cm})$ & Surface & Weight (g) & Pretreatment & Flotation & Sieving \\
\hline 18 & $?$ & $?$ & $?$ & $?$ & $?$ & $?$ & $?$ \\
\hline 19 & Children & 10 & $?$ & 250 & $?$ & $?$ & $?$ \\
\hline 20 & $?$ & 5 & $?$ & $?$ & ? & $\mathrm{MgSO}_{4}+\mathrm{KI}$ & No \\
\hline 21 & Random & Various & $100 \mathrm{~cm}^{2}$ & 200 & $\mathrm{NaCl}+$ water & Brine & No \\
\hline 22 & Children & 1 & $15 \mathrm{~cm}^{2}$ & $?$ & $?$ & $\begin{array}{c}\mathrm{ZnSO}_{4}+ \\
\mathrm{NaOH}\end{array}$ & No \\
\hline 8 & $?$ & 12 & $?$ & 75 & Water & $\mathrm{ZnSO}_{4}$ & No \\
\hline 23 & Animal & $?$ & $?$ & $450-2350$ & Water & NA & Yes \\
\hline 24 & Random & $8-10$ & $3-4 \mathrm{~cm}^{\dagger}$ & $500-600$ & Water & NA & Yes \\
\hline 9 & $?$ & 40 & $3.5 \mathrm{~cm}^{\dagger}$ & $250-300$ & Water & $\mathrm{NaCl}$ & No \\
\hline 25 & Children & 15 & $?$ & 1000 & Water & $\mathrm{KIHg}$ & No \\
\hline 26 & Systematic & 10 & $?$ & $250-300$ & Water + mesh & Saline & No \\
\hline 27 & Animal & 10 & $?$ & 250 & $\begin{array}{l}\text { Hypochlorite } \\
\text { sodium }\end{array}$ & $\mathrm{NaCl}$ & No \\
\hline 28 & Systematic & Surface & $?$ & 1000 & Tween 80 & Sugar & Yes \\
\hline 29 & Children & 2 & $130 \mathrm{~cm}^{2}$ & 250 & None & $\mathrm{NaNO}_{3}$ & No \\
\hline 30 & Random & 1 & $1 \mathrm{~m}^{2}$ & 450 & Tween 80 & $\mathrm{NaNO}_{3}$ & No \\
\hline 31 & Systematic & Upper & $1000 \mathrm{~cm}^{2}$ & $?$ & Water + mesh & $\mathrm{NaNO}_{3}$ & No \\
\hline 32 & Systematic & 3 & $6 \mathrm{~cm}^{\dagger}$ & $100-150$ & $?$ & Sucrose & No \\
\hline 33 & ? & 10 & $?$ & $250-300$ & None & $\mathrm{ZnSO}_{4}$ & No \\
\hline 34 & $?$ & Surface & $?$ & 10 & $?$ & $\mathrm{ZnSO}_{4}$ & No \\
\hline 35 & ? & 5 & $?$ & 10 & Teepol + sieve & $\mathrm{ZnSO}_{4}$ & Yes \\
\hline 36 & $?$ & 3 & $?$ & $?$ & Tween 80 & $\mathrm{MgSO}_{4}+\mathrm{KI}$ & No \\
\hline 37 & $?$ & 3 & $100 \mathrm{~cm}^{2}$ & $?$ & Tween 60 & $\mathrm{MgSO}_{4}+\mathrm{KI}$ & No \\
\hline 38 & Systematic & $?$ & $?$ & 250 & Water & $\mathrm{ZnSO}_{4}$ & No \\
\hline 39 & Systematic & 3 & $?$ & 200 & Tween 60 & $\mathrm{ZnSO}_{4}$ & No \\
\hline 40 & $?$ & $?$ & ? & 50 & Tween 80 & $\mathrm{MgSO}_{4}$ & No \\
\hline 41 & $?$ & 0.5 & $15 \times 15 \mathrm{~cm}^{2}$ & $?$ & Tween 60 & $\mathrm{NaNO}_{3}$ & No \\
\hline 42 & Systematic & $0.5-1$ & $930 \mathrm{~cm}^{2}$ & 250 & $\mathrm{NaOH}$ & $\mathrm{ZnSO}_{4}$ & No \\
\hline 43 & ? & Upper & $?$ & $?$ & $?$ & $\mathrm{ZnSO}_{4}$ & No \\
\hline 44 & Children & $?$ & $?$ & $?$ & Tween 40 & $\mathrm{NaNO}_{3}$ & No \\
\hline 45 & Animal & 1 & $?$ & 250 & Tween 60 & $\mathrm{ZnSO}_{4}$ & No \\
\hline 46 & Systematic & $?$ & $?$ & 50 & Tween 40 & $\mathrm{NaNO}_{3}$ & No \\
\hline 47 & Systematic & $1-2$ & $?$ & 40 & Tween 40 & $\mathrm{NaNO}_{3}$ & No \\
\hline 48 & & $0.5-1$ & $500 \mathrm{~cm}^{2}$ & 250 & $\mathrm{~N} \mathrm{NaOH}$ & $\mathrm{ZnSO}_{4}$ & No \\
\hline
\end{tabular}

*Method by which the sample was taken: children - from areas where children play; animals - from areas where animals are expected to defecate; systematic; random. ${ }^{\dagger}$ Diameter of sample. ? Indicates that this information is not provided in the publication. KI Potassium lodide; KI Potassium lodine; KIHg Mercury potassium iodide; $\mathrm{MgSO}_{4}$ Magnesium sulphate; $\mathrm{NaNO}_{3}$ Sodium nitrate; $\mathrm{NaOH}$ Sodium hydroxide; $\mathrm{ZnSO}_{4}$ Zinc sulphate

Judgement 1 method (J1): In order to assess soil contamination by sand or soil-associated microorganisms, the World Health Organization (WHO) recommends that sand be sampled in shaded areas and near trees (49). Therefore, this judgement method focused on covered areas, places where traces of cats were visible, areas near walls and shaded areas.

Judgement 2 method (J2): Areas where children were the most likely to play were sampled in the sandbox and in the play area. These areas were identified by observing children at play.
The nine-day period was divided into three blocks of three days each. The three methods were each used once in each block. For each three-day block, the order of the sampling method used each day was chosen at random in order to avoid an order effect. The order of the sampling methods is described in Table 3.

All 25 areas of the sandbox and all 25 areas of the play area were sampled on day 10.

Sand sampling for laboratory analysis: The sampling took place every morning before the arrival of the children at the DCC. In each selected area, $100 \mathrm{~g}$ of sand were obtained, to a depth of $10 \mathrm{~cm}$, with a $4 \mathrm{~cm}$ diameter sterile container for bac- 


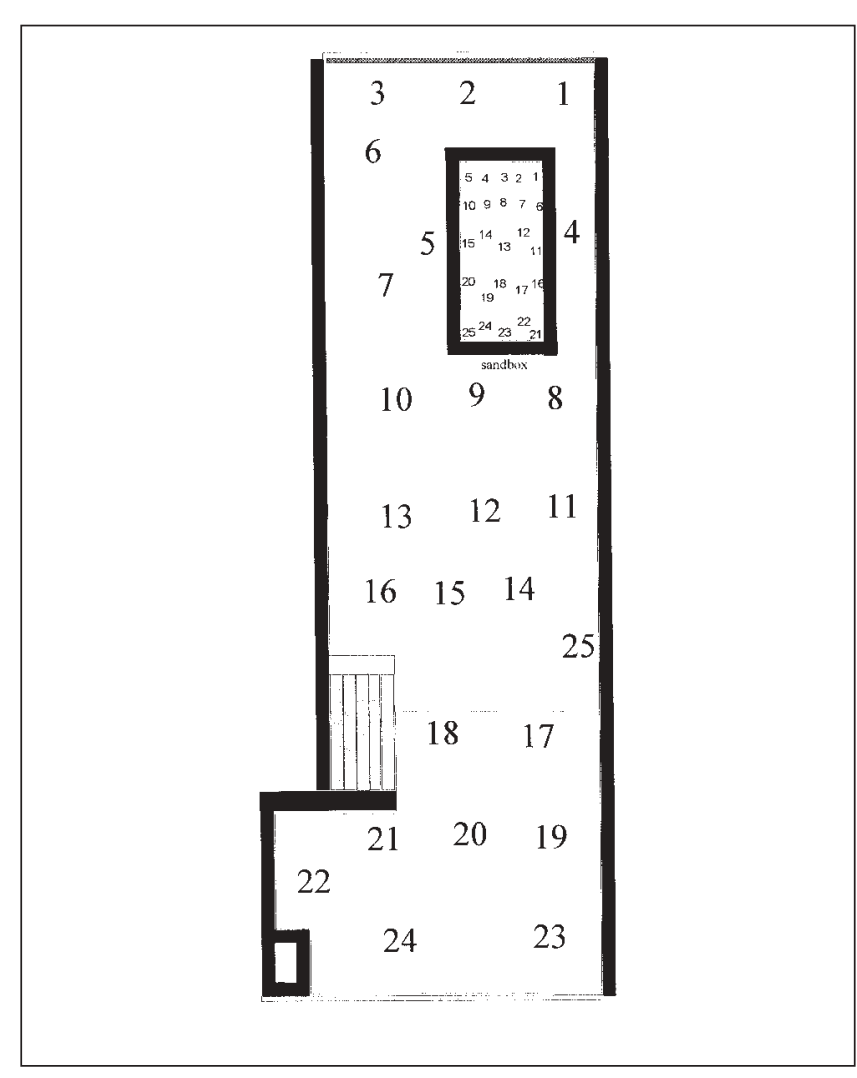

Figure 1) Division of sandbox and play area into 25 areas for sampling

TABLE 3

Order in which areas at day care centre where sampled

\begin{tabular}{llll|lll|lll}
\hline Block & \multicolumn{3}{c}{$\mathbf{1}$} & \multicolumn{3}{c}{$\mathbf{2}$} & & \multicolumn{3}{c}{$\mathbf{3}$} \\
\hline Method & J2 & R & J1 & J1 & R & J2 & R & J1 & J2 \\
\hline
\end{tabular}

11 Judgement 1 method; J2 Judgement 2 method; R Random method

teriological analysis. The container was placed at $4^{\circ} \mathrm{C}$ until it was transported to the laboratory, where it was immediately processed (within $1 \mathrm{~h}$ of sampling). Another $100 \mathrm{~g}$ of sand, similarly obtained, was placed in a container filled with sodium-acetic acid-formalin (SAF) for the parasitological analysis.

Method of quantification of the FCs: Bacteriological analyses were performed at the Centre de recherche en virologie, Institut Armand-Frappier, location. A membrane filtration method for the identification of FCs was used (50). First, the sand was shaken to homogenize the sample. Then, $10 \mathrm{~g}$ was weighed and placed in a solution of $100 \mathrm{~mL}$ phosphatebuffered saline $10 \times$. The samples were left at $4^{\circ} \mathrm{C}$ for $24 \mathrm{~h}$. The sample was filtered, placed on $\mathrm{m}-\mathrm{FC}$ medium and incubated at $44^{\circ} \mathrm{C}$ for $24 \mathrm{~h}$. Blue colonies with metallic sheen were counted.

Recovery methods for Toxocara species: Parasitological analyses were performed at the Centre for Tropical Diseases at the Montreal General Hospital, Montreal, Quebec. Recovery of Toxocara species ova from sand included a pretreatment stage to homogenize the sand and to 'unstick' the ova from the sand particles. A flotation-centrifugation method was used to separate and collect the ova from the sand sediment.
TABLE 4

Fecal coliforms (FCs) recovered from the study sandbox and play area

\begin{tabular}{|c|c|c|c|c|c|c|}
\hline \multirow[b]{3}{*}{ Method ${ }^{*}$} & \multirow{2}{*}{\multicolumn{3}{|c|}{$\begin{array}{l}\text { Number of FCs } \\
\text { (number of } \\
\text { colonies/g sand) } \\
\text { from sandbox } \\
\text { Block }\end{array}$}} & \multirow{2}{*}{\multicolumn{3}{|c|}{$\begin{array}{c}\text { Number of FCs } \\
\text { (number of } \\
\text { colonies/g sand) } \\
\text { from play area } \\
\text { Block }\end{array}$}} \\
\hline & & & & & & \\
\hline & 1 & 2 & 3 & 1 & 2 & 3 \\
\hline \multirow[t]{5}{*}{ Random } & 200 & 200 & 260 & 460 & 250 & 96 \\
\hline & 1020 & 2800 & 115 & 1 & 2100 & 750 \\
\hline & 100 & 10,500 & 690 & 2 & 24 & 0 \\
\hline & 16 & 18 & 149 & 34 & 10 & 70 \\
\hline & 87 & 18 & 4640 & 152 & 24,800 & 130 \\
\hline Average & 285 & 2707 & 1171 & 130 & 5437 & 1046 \\
\hline \multirow{5}{*}{$\begin{array}{l}\text { Judge- } \\
\text { ment } 1 \\
\text { 'animal' }\end{array}$} & 21 & 140,000 & 1050 & 240 & 25,000 & 1090 \\
\hline & 7 & 17 & 5 & 50 & 620 & 610 \\
\hline & 270 & 380 & 1680 & 3840 & 530 & 230 \\
\hline & 40 & 30 & 7200 & 0 & 1 & 4110 \\
\hline & 4 & 7 & 54 & 4 & 22 & 80 \\
\hline Average & 68 & 28,087 & 1998 & 827 & 5235 & 779 \\
\hline \multirow{5}{*}{$\begin{array}{l}\text { Judge- } \\
\text { ment } 2 \\
\text { 'children' }\end{array}$} & 800 & 430 & 1440 & 48 & 28 & 215 \\
\hline & 4360 & 370 & 460 & 260 & 610 & 2480 \\
\hline & 2810 & 1770 & 900 & 570 & 230 & 3870 \\
\hline & 790 & 210 & 680 & 330 & 4110 & 210 \\
\hline & 170 & 68 & 1000 & 12 & 8 & 13 \\
\hline Average & 2186 & 570 & 896 & 244 & 997 & 1358 \\
\hline
\end{tabular}

${ }^{*}$ See text for explanation of methods used

One millilitre of Tween 80 solution (Anachema, Quebec) was added to the sand sample ( $100 \mathrm{~g}$ ) diluted in SAF to obtain a $0.1 \%$ solution and then shaken for $1 \mathrm{~min}$. This solution was poured into $15 \mathrm{~mL}$ centrifuge tubes and centrifuged for $2 \mathrm{mins}$ at $700 \mathrm{~g}$. The supernatant was discarded. The sediment was then suspended in a solution of zinc sulphate (specific gravity 1.2) (51) and centrifuged for 2 mins at $\times 700 \mathrm{~g}$. A small amount of the supernatant was pipetted and placed on a microscope slide. The slide was examined promptly at $40 \times$ magnification.

Statistical analyses: The results are described by sampling method and by block. A logarithmic transformation ( $\left.\log _{10}\right)$ was used because the data were not normally distributed. Ninety-five per cent confidence intervals were calculated for the difference in FC counts in the play area and the sandbox. SAS software (Statistical Analysis Systems Institute Inc, North Carolina) was used to obtain summary statistics (quartiles, $95 \% \mathrm{CI}$, median, ranges).

\section{RESULTS}

FCs: FC counts by method and by block for the sandbox and the play area are shown in Table 4. The FC counts varied extensively from area to area and from day to day. All three methods almost constantly underestimated the overall contamination found on the last day of sampling. Only in one instance did the J2 method (where children play) provide a FC count higher than 
TABLE 5

Presence of Toxocara species in the study sandbox and play area

\begin{tabular}{|c|c|c|c|c|c|c|}
\hline \multirow[b]{2}{*}{ Method } & \multicolumn{3}{|c|}{$\begin{array}{c}\text { Sandbox } \\
\text { Block }\end{array}$} & \multicolumn{3}{|c|}{$\begin{array}{c}\text { Play area } \\
\text { Block }\end{array}$} \\
\hline & 1 & 2 & 3 & 1 & 2 & 3 \\
\hline \multirow[t]{5}{*}{ Random } & - & - & - & - & - & - \\
\hline & - & - & - & - & - & - \\
\hline & - & - & - & - & + & - \\
\hline & - & - & - & - & - & - \\
\hline & - & - & - & - & - & - \\
\hline \multirow{5}{*}{$\begin{array}{c}\text { Judgement } 1 \\
\text { 'animal' }\end{array}$} & - & + & - & - & - & - \\
\hline & - & - & - & - & - & - \\
\hline & - & - & + & - & - & - \\
\hline & - & - & - & + & - & - \\
\hline & - & + & - & - & - & - \\
\hline \multirow{5}{*}{$\begin{array}{c}\text { Judgement } 2 \\
\text { 'children' }\end{array}$} & - & - & + & - & - & + \\
\hline & - & - & - & - & - & - \\
\hline & - & - & - & - & - & - \\
\hline & - & - & - & - & + & - \\
\hline & - & - & - & - & - & - \\
\hline
\end{tabular}

the count on day 10. However, because of the extreme variation in the FC levels both within the same day and between days, there was insufficient power to conduct any meaningful parametric or nonparametric test. Therefore, it was not possible to identify a method that was superior to the other methods.

On the last day of sampling (day 10), the average counts were $3036 \pm 7700 \mathrm{FCs} / \mathrm{g}$ and $915 \pm 930 \mathrm{FCs} / \mathrm{g}$ of sand for the play area and the sandbox, respectively. These counts were not normally distributed. The median counts of $\mathrm{FC}$ were $910 \mathrm{FCs} / \mathrm{g}$ (interquartile range $[\mathrm{IQR}]=1050$ ) and $350 \mathrm{FCs} / \mathrm{g}$ $(\mathrm{IQR}=1160$ of sand for the sandbox and the play area, respectively). The difference in the log transformed FC counts between the play area and sandbox was 0.0093 with a $95 \% \mathrm{Cl}$ of -0.5589 to 0.5776 .

Toxocara species: The areas where Toxocara species ova were found using the different sampling methods for the three blocks are shown in Table 5. Because very few ova were recovered in each sample, a qualitative measure was used to describe the presence or absence of Toxocara species. No differentiation was made between Toxocara canis and Toxocara cati. The recovery varied considerably from one sampling area and day to another. Figure 2 shows the areas in which toxocara ova were recovered on the last day of sampling. Toxocara ova were recovered in one area of the sandbox and in six areas of the play area. The presence of toxocara ova was not associated with any particular region of the play area.

\section{DISCUSSION}

The number of FCs and the presence of Toxocara species recovered from the play area and the sandbox of the study day care centre varied extensively, both in time and space. Envi-

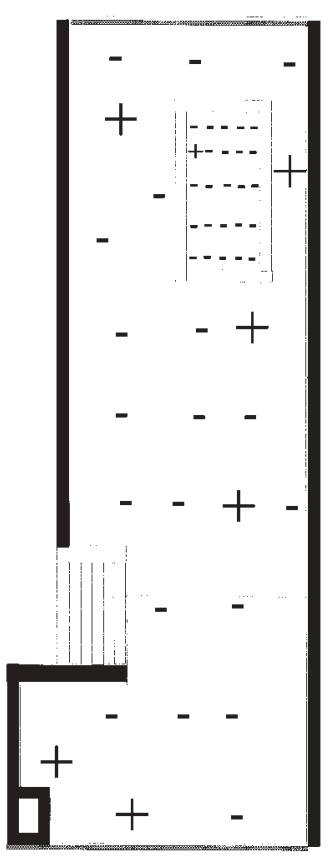

Figure 2) Spatial distribution of the presence of Toxocara species (+) on the last day of sampling. - No Toxocara species present

ronmental factors, such as temperature and humidity, and physical factors, such as the shifting of sand by children or animals, and the presence of domestic and small wild animals or birds defecating in different areas of the playground on different days may partially explain the observed variation.

In Quebec, the presence of animals in DCCs is prohibited (52). In addition, outdoor playgrounds of DCCs must be surrounded by a fence of at least $1.2 \mathrm{~m}$ in height (52). However, no mention is made of the spacing between the ground and the lower perimeter of the fence or fence maintenance. Small animals such as dogs, cats and raccoons consequently may have access to the playgrounds. In a 1994 study of 10 DCCs from three different geographical regions of Quebec (Quebec City, Trois-Rivière and Montreal), the presence of dogs, cats, raccoons, pigeons and mice during the night was reported by four DCC directors (8).

Due to the magnitude of the random variation in bacterial and parasite contamination observed, a statistical comparison among the three sampling methods was not possible. To best represent the overall level of contamination in the outdoor DCC environment (sandbox and play area), results from the sampling of all squares (as observed from the results obtained on day 10) were determined to be the most useful.

To evaluate the importance of the level of contamination found, we obtained the microbiological standards (for total and FC contamination) established by Ministère de l'Agriculture, des Pêcheries et de l'Alimentation du Québec for the interpretation of the results of food analyses (53). For example, $30 \mathrm{FCs} / \mathrm{g}$ is the upper 'acceptable' limit of contamination in molluscs prepared for human consumption; a norm of 1000 total coliforms is the upper limit in ice milk. The proportion of 
FCs to total coliforms varies considerably from one medium to another (personal communication) but to our knowledge, no standards have been established for sand. Standards used by the Ministère de l'Environnement du Québec in assessing beach water contamination are $200 \mathrm{FCs} / 100 \mathrm{~mL}$ (55). The results we obtained (medians of 350 and $910 \mathrm{FCs} / \mathrm{g}$ of sand from the sandbox and play area, respectively) are clearly higher than these standards. Indoor FC contamination from surfaces, toys, and from children's and staff's hands has been reported at (median) levels between 0 and 39.8 FCs (5). Although our results from sand cannot be directly compared with results from food, water, indoor surfaces or hands, they indicate significant fecal contamination.

Based on data obtained over a two-week period, 65 children age one to four years were reported to have ingested a median of $40 \mathrm{mg}$ of soil per day in a DCC setting in the United States (55). One child in this study had ingested 5 to $8 \mathrm{~g}$ of soil per day. Using our data, it is possible, therefore, that children playing in a play area contaminated with an average of 1000 $\mathrm{FCs} / \mathrm{g}$ of sand, could ingest a median of $40 \mathrm{FCs}$ per day.

Our study confirms previous reports documenting the presence of Toxocara species ova in the outdoor DCC environment. This result may have been missed if the sampling method had been limited to one method only. It is impossible to know whether this is due to a poor recovery rate due to the method itself, because the sand is moved by children and animals each day or because the samples were not taken exactly at the same place from day to day. The percentage recovery of toxocara ova in experimental studies is reported to range from $0 \%$ to $70 \%$, but

\section{REFERENCES}

1. Bartlett A, Moore M, Gary G, Starko K, Erben J, Meredith B. Diarrheal illness among infants and toddlers in child care centers. II. Comparison with day care homes and households. J Pediatr 1985;107:503-9.

2. Collet JP, Burtin P, Kramer MS, et al. Type of day care setting and risk of recurrent infection. Respiration 1994;61(Suppl 1):16-9.

3. Fleming DW, Cochi SL, Hightower AW, Broome CV. Childhood upper respiratory tract infections: To what degree is incidence affected by day-care attendance? Pediatrics 1987;79:55-60.

4. Thompson SC. Infectious diarrhoea in children: Controlling transmission in the child care setting. J Pediatr 1994;30:210-9.

5. Laborde D, Weigle C, Weber D, Kotch J. Effect of fecal contamination on diarrheal illness rates in day-care centers. Am J Epidemiol 1993;138:243-55.

6. Soto JC. Infectious disease control in daycare centres: a Canadian experience. Can J Pediatr 1993;5:330-6.

7. Black R, Merson M, Huq I, Alim A, Yunus M. Incidence and severity of rotavirus and Escherichia coli diarrhea in rural Bangladesh: implications for vaccine development. Lancet $1981 ; \mathrm{i}: 141-3$.

8. Gyorkos TW, Kokoskin-Nelson E, MacLean JD, Soto JC. Parasite contamination of sand and soil from daycare sandboxes and play areas. Can J Infect Dis 1994;5:17-20.

9. Gasquet M, Julien J, Delmas F, Andrac A, Timon-David P. Étude parasitologique des bacs à sable et sables de plages de la région de Marseille. Rev Fr Santé Publ 1986;35:33-43.

10. Acha N, Szyfres B. Zoonoses et maladies transmissibles communes à l'homme et aux animaux. Paris: Office international des épizooties, 1989.

11. Keswick B, Pickering L, Dupont H, Woodward W. Survival and detection of rotaviruses on environmental surfaces in day care centers. Appl Environ Microbiol 1983;46:813-7.

12. Chabasse D, Bouchara JP, Rivet M. Étude parasitologique et mycologique des bacs à sable des aires de jeux de this can vary with the number of grams processed, the level of contamination, the pretreatment techniques, the type of flotation solution used and the type of sand/soil examined (36,56-60). Consequently, the prevalence of toxocara observed can only be an underestimate of the true level of contamination.

\section{CONCLUSION}

The contamination levels found in this study indicate a risk of potentially pathogenic bacterial and parasite contamination in the outdoor day care environment. The most representative levels of bacterial contamination were found in a combined sample of the total surface area rather than from a random or judgement sampling method. Research on environmental microbial contamination of outdoor day care settings would benefit from the application of standardized and validated sampling and laboratory methods.

ACKNOWLEDGEMENTS: This work was supported by the Animal Branch of Pfizer Canada and, in part, by the National Health Research and Development Program (NHRDP) through a National Health Research Scholar Award to Theresa W Gyorkos; by NHRDP and the Fonds pour la formation de Chercheurs et l'Aide à la Recherche (FCAR) through a doctoral fellowship to Hélène Carabin; and by the Fonds de la Recherche en Santé du Québec (FRSQ) through a Chercheur boursier to Lawrence Joseph. Denis Minville provided expert assistance with the bacteriological analyses. The authors gratefully acknowledge all the day care centres that participated in this study, particularly the day care centre in which the complete series of sampling methods were studied.

l'agglomération angevine. Médecine Maladies Infectieuses 1983;13:436-42.

13. Zurawska-Olszewska J, Misiak G. Preliminary evaluation of biological-sanitary contamination of grass lawns and children playgrounds in Warsaw in 1991. Medycyna Doswiadczalna i Mikrobiologia 1994;46:103-6.

14. Quessy S, Messier S. Prevalence of Salmonella spp, Campylobacter spp and Listeria spp in ring-billed gulls (Larus delawarensis). J Wildl Dis 1992;28:526-31.

15. Comité provincial des maladies infectieuses en garderie. Le comité provincial des maladies infectieuses en service de garde répond à vos questions. In: Comité organisateur d'événements pour les services de garde à l'enfance, ed. Actes du Colloque québecois sur les services de garde à l'enfance. Actes du Colloque québécois sur les services de garde à l'enfance. Montréal, 1991:147-50.

16. Canadian Paediatric Society. Well Beings: A Guide to Promote the Physical Health, Safety and Emotional Well-being of Children in Child Care Centers and Family Day Care Homes. Ottawa: Canadian Paediatric Society, 1992:98-9.

17. American Public Health Association and American Academy of Pediatrics. National health and safety performance standards: Guidelines for out-of-home child care program. In: Chang A, ed. Caring for Our Children. Elk Grove: American Academy of Pediatrics, 1992:363.

18. Dunsmore JD, Thompson RCA, Bates IA. Prevalence and survival of Toxocara canis in the urban environment of Perth, Australia. Vet Parasitol 1984;16:303-11.

19. Winkel KD, Saw TH, Prociv P. Risk of parasitic infections from sandpits. Med J Aust 1990;153:503. (Lett)

20. Costa-Cruz JM, Nunes RS, Buso AG. Presença de ovos de Toxocara spp em praças públicas da cidade de Uberlândia, Minas Gerais, Brasil Rev Inst Med Trop Säo Paulo 1994;36:39-42.

21. Ghadirain E, Viens P, Dubreuil F. Epidemiology of toxocariasis in 
the Montreal area. Prevalence of Toxocara and other helminth ova in dogs and soil. Can J Public Health 1976;67:495-8.

22. Gualazzi DA, Embil JA, Pereira LH. Prevalence of helminth ova in recreational areas of peninsular Halifax, Nova Scotia. Can J Public Health 1986;77:147-51.

23. Laborde C, Bussieras J, Chermette R. Recherche des oeufs de Toxocara spp. dans le sol des jardins de Paris. Prophylaxie des infestations humaines. Rec Med Vet Ec Alfort 1980;156:733-8.

24. Chabasse D, Rivet M. Recherche des oeufs de Toxocara species dans les bacs à sable des aires de jeux de l'agglomération angevine. Ouest Med 1982;35:807-10.

25. Doucet M. Étude de la contamination des bacs à sable de la ville de Lyon par Toxocara canis. Thèse de D.M.V. Lyon: École nationale vétérinaire de Lyon, 1994.

26. Duwell D. The prevalence of toxocara eggs in the sand in children's playgrounds in Frankfurt/M. Ann Trop Med Parasitol 1984;78:633-6.

27. Knaus VB-U, Lange U, Volcsik R. Larva migrans visceralis Occurrence of ascarid eggs in sand-pits in the GDR district town of Cottbus. Angewandte Parasitologie 1987;28:81-3.

28. Horn K, Schieder T, Stoye M. Contamination of public children playgrounds with helminth eggs in Hannover (German). Dtsch Tierärztl Wschr 1990;97:122-5.

29. Holland C, O'Connor P, Taylor MR, Hughes G, Girdwood RWA, Smith H. Families, parks, gardens and toxocariasis. Scand J Infect Dis 1991;23:225-31.

30. O'Lorcain P. Prevalence of Toxocara canis ova in public playgrounds in the Dublin area of Ireland. J Helminthol 1994;68:237-41.

31. Shimizu T. Prevalence of toxocara eggs in sandpits in Tokushima city and its outskirts. J Vet Med Sci 1993;55:807-11.

32. Uga S. Prevalence of toxocara eggs and number of fecal deposits from dogs and cats in sandpits of public parks in Japan. J Helminthol 1993;67:78-82.

33. Abo-Shehada MN. Prevalence of Toxocara ova in some schools and public grounds in northern and central Jordan. Ann Trop Med Parasitol 1989;83:73-5.

34. Thompson DE, Bundy DAP, Cooper ES, Schantz PM. Epidemiological characteristics of Toxocara canis zoonotic infection of children in a Carribean community. Bull WHO 1986;64:283-90.

35. Jansen J, van Knappen F, Schreurs M, van Wijngaarden Th. Toxocara eieren in parken en zandbakken in de stad Utrecht. Tijdschr Diergeneeskd 1993;118:611-4.

36. Quinn R, Smith HV, Bruce RG, Girdwood RWA. Studies on the incidence of Toxocara and Toxascaris spp ova in the environment. 1. A comparison of flotation procedures for recovering Toxocara spp ova from soil. J Hyg (Lond) 1980;84:83-9.

37. Conde Garcia L, Muro Alvarez A, Simon Martin F. Epidemiological studies on toxocariasis and visceral larva migrans in a zone of Western Spain. Ann Trop Med Parasitol 1989;83:615-20

38. Borg OA, Woodruff AW. Prevalence of infective ova of Toxocara species in public places. Br Med J 1973;4:470-2.

39. Snow KR, Ball SJ, Bewick JA. Prevalence of Toxocara species eggs in the soil of five east London parks. Vet Rec 1987;120:66-7.

40. Gillepsie SH, Ramsay A. The prevalence of Toxocara canis ova in soil samples from parks and gardens in the London area. Public Health 1991;105:335-9.

41. Dubin S, Segall S, Martindale J. Contamination of soil in two city parks with canine nematode ova including Toxocara canis: a preliminary study. Am J Public Health 1975;65:1242-5.

42. Dada BJO, Lindquist WD. Studies on flotation techniques for the recovery of helminth eggs from soil and the prevalence of eggs of Toxocara spp in some Kansas public places. J Am Vet Med Assoc 1979;174:1208-10.

43. Surgan MH, Colgan KB, Kennett BS, Paffman JV. A survey of canine toxocariasis and toxocaral soil contamination in Essex County, New Jersey. Am J Public Health 1980;760:1207-8.

44. Smith RE, Hagstad H, A'Beard GB. Visceral larva migrans: a risk assessment in Baton Rouge, Louisiana. Int J Zoonoses 1984;11:189-94.

45. Childs JE. The prevalence of Toxocara species ova in backyards and gardens of Baltimore, Maryland. Am J Public Health 1985; $75: 1092-4$

46. Paul AJ, Tood KS, Dipietro JA. Environmental contamination by eggs of Toxocara species. Vet Parasitol 1988;26:339-42.

47. Ludlam KE, Platt TR. The relationship of park maintenance and accessibility to dogs to the presence of Toxocara spp ova in the soil. Am J Public Health 1989;79:633-4.

48. Rapic D. Kontaminiranost javih povrsina jajascima helminata. Vet Arch 1983;53:233-8.

49. World Health Organization (WHO) Expert Committee on the Control of Ascariasis. Control of Ascariasis $r$ eport of a WHO expert committee. World Health Organization Technical Report Series no 379. Geneva: WHO, 1967:14-22.

50. American Public Health Association. Standard Methods for the Examination of Water and Wastewater, 18th edn. Washington: American Public Health Association, 1992.

51. Ash LR, Orinel TC. Parasites: A Guide to Laboratory Procedures and Identification. Chicago: American Society of Clinical Pathology Press, 1987.

52. Editeur officiel du Québec. Règlement sur les services de garde en garderie. [S-4.1,r.2]: Article \#43. Québec: Gouvernement du Québec, 1994.

53. Comité sur l'uniformisation des méthodes d'analyses et l'interprétation des résultats analytiques. Critères microbiologiques pour l'interprétation des résultats en analyse alimentaire. Gouvernement du Québec, ed. Québec: Ministère de l'Agriculture, des Pêcheries et de l'Alimentation du Québec, 1993.

54. Thibault M, Blaney S, Lévesque B. Étude de la contamination microbiologique du fleuve Saint-Laurent et ses tributaires et impacts possibles sur la santé humaine. Québec: Centre de santé publique de Québec, Équipe Santé et environnement, 1995.

55. Calabrese EJ, Barnes R, Stanek EJ, et al. How much soil do young children ingest: an epidemiologic study. Reg Toxicol Pharmacol 1989;10:123-37.

56. Dada BJO. A new technique for the recovery of toxocara eggs from soil. J Helminthol 1979;53:141-4.

57. Delmas F, Gasquet J, Julien J, Timon-David P. Intérêt de la standardisation des méthodes de recherche parasitologiques dans les bacs à sable. Rev Fr Santé Publ 1988;42:13-7.

58. Horn K, Schieder T, Stoye M. Quantitative comparison of various methods for detecting eggs of Toxocara canis in samples of sand. J Vet Med (Ser B) 1990;37:241-50.

59. Kazacos KR. Improved method for recovering ascarid and other helminth eggs from soil associated with epizootics and during survey studies. Am J Vet Res 1983;44:896-900.

60. Nunes CM, Sinhorini IL, Ogassawara S. Influence of soil in the recovery of Toxocara canis eggs by a flotation method. Vet Parasitol 1994:54:269-74. 


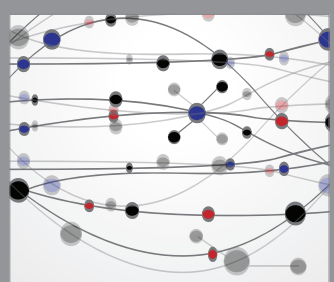

The Scientific World Journal
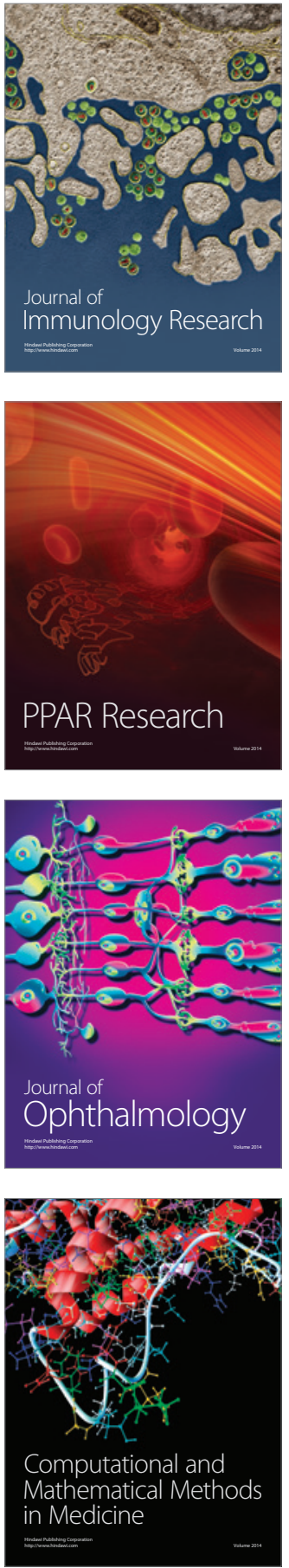

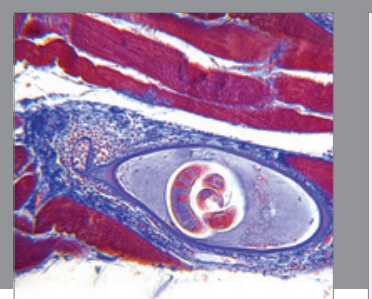

Gastroenterology Research and Practice

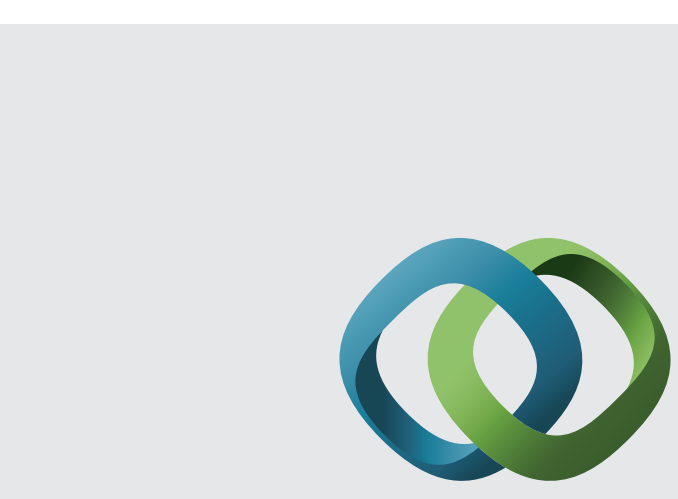

\section{Hindawi}

Submit your manuscripts at

http://www.hindawi.com
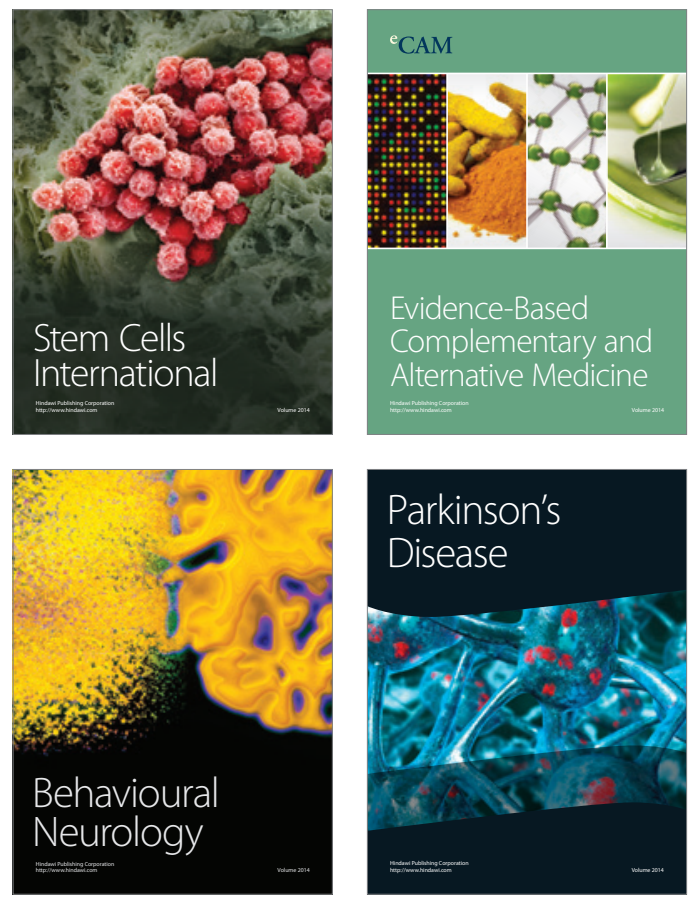
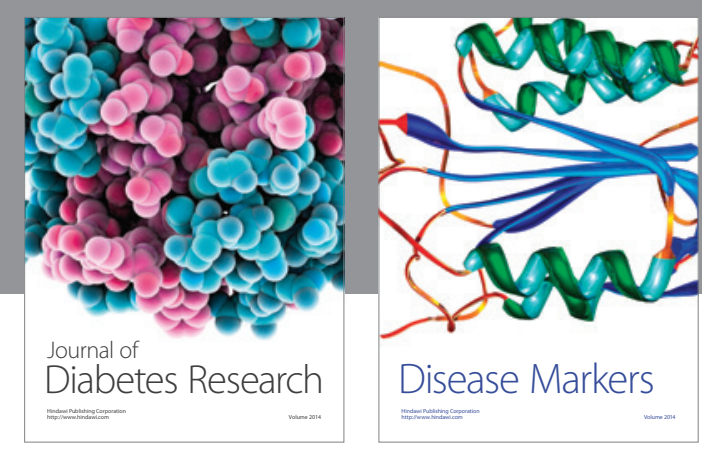

Disease Markers
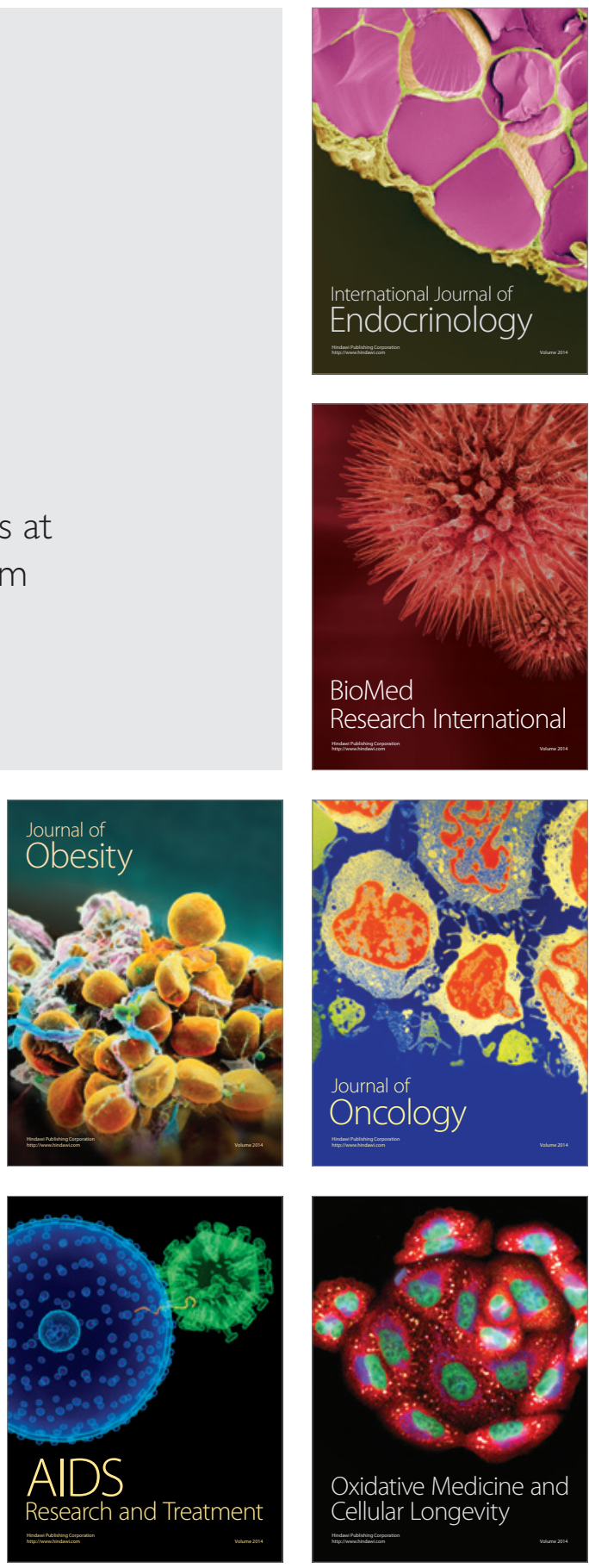